Palestine Exploration Quarterly

\title{
The Acra
}

\section{Charles Watson}

To cite this article: Charles Watson (1906) The Acra, Palestine Exploration Quarterly, 38:1, 50-54, DOI: 10.1179/peq.1906.38.1.50

To link to this article: http://dx.doi.org/10.1179/peq.1906.38.1.50

曲 Published online: 20 Nov 2013.

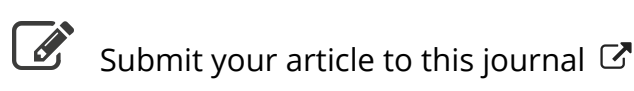

Џll Article views: 4

Q View related articles $\sqsubset$ 
Then another violent conflict broke out in the district of Bani Murrah, between Sheikh Maḥmûd aba Mubârak of Silwâd and 'Abd el-'Azîz el-Ansawiyah of el-Mazra'a. Husain and Mahmoud came to the help of the former, Salah 'Abd el-Jabbâr to assiat the latter. The seat of the conflict was at Silwâd and Yebrad. The fighting lasted two months, and many were killed on both sides. But after this a new governor came to Jerusalem, who ordered the fighting to cease, and commanded the destruction of all strongholds and fortifications. He also commanded each of the sheikhs to be confined to his own district.

Shortly afterwards, command from the Sultan 'Abd el-'Aziz came to the effect that the sheikhs should all be dismissed, and Turkish officials put in their place, and that the taxes should be paid directly to the central government. Thus the country at last obtained rest from the oppression and quarrelsomeness of the sheikhs.

\section{Note added in the Press.}

The following list of governors, with dates, is compiled with the help of Finn's Stirring Times.

'Ali Pasha, 1845.

Muhammad Pasha el-Kubrusli, 1846-( ( ).

Muhammad Hâfiz, 1852-17 Dec., 1853.

Yâkûb Pasha, March, 1854-20 Oct., 1854.

Mehmet Kiamil Pasha, 15 Feb., 1855-(?).

It is impossible to be sure of the exact order of the events above recorded, as there is evidence that they are not detailed systematically in the MSS. which we have used.

\section{THE ACRA.}

By Sir Charles Watson, K.C.M.G., C.B., R.E., M.A.

ONE of the questions respecting the topography of ancient Jerusalem which has been frequently discussed in the Palestine Fund Quarterly Statement is that concerning the position of the fortress known as the "Acra" of the Maccabees and Josephus, and the views as regards the place it occupied are as divergent as those concerning the site of the Temple or of the Holy Sepulchre. For 
example, Sir Charles Warren and Colonel Conder, whose opinions must always be regarded with respect, have held that the Acra was on the east side of the hill upon which the Emperor Constantine built the Church of the Resurrection, while the Rev. W. F. Birch, who has given long and careful study to the question, is convinced that it was situated on the slope of the hill south of the Haram enclosure.

Having regard to all that has been written upon the subject, it is with some diffidence that I venture to suggest that the Acra was built on a site different to either of the above, and one which, so far as I am aware, has not hitherto been proposed. My excuse is, that a setting forth of my views, even if they are not accepted, may be of some help to those who take an interest in the topography of Jerusalem.

In order to arrive at an opinion upon the subject we have to depend upon the historical statements in the Bible, the Apocrypha, and Josephus, as well as on the actual knowledge of the ground which has been gained in recent years by the surveys made by Sir Charles Wilson, and the explorations carried out by Sir Charles. Warren, Colonel Conder, and others. For convenience of reference, I have given below a list of the passages in the ancient writers. which bear upon the question. ${ }^{1}$

1 The following are the passages in the Bible, the Apocrypha, and Josephus, which refer to the subject:-

The Bible:

Joshua $x \nabla, 8,63$; xviii, 16.

Judges i, 8, 21.

2 Samuel $\nabla, 6-9$; xxiv, 18, 19.

1 Kings viii, 1 ; ix, 15, 24; $x i, 27$.

2 Kinge $x \times i i, 14$.

The Apocrypla: :

1 Maccabees i, 33; iv, 37; vi, 18; vii, 33; xi, 41 ; xii, 36; xiii, 21, 49-52; xiv, 36, 37 .

Josephus: "The Antiquities of the Jews."

Book V, chap. i ; chap. ii, 5.

" VII, chap. iii, 1, 2.

"XII, chap. iii, 3 ; chap. $\nabla, 4$; chap. vii, 6 ; chap. ix, 3 ; ohap. $x, 5$.

"XIII, chap. $i, 3$; chap. ii, 1 ; chap. iv, 9 ; chap. $\nabla, 11$; chap. vi, 6 ; chap. vii, 7 .

Josephus: "The Wars of the Jews."

Book I, chap. $i, 4$.

"V, chap. iv, 1 ; chap. vi, 1.

"VI, clan. vi, 3.
1 Chronicles $\mathrm{xi}, 4-8$; $\mathrm{xxi}, 18$.

2 Chronicles iii, 1 ; $\vee, 2$; $\times x \times$ ii, 5 ; xxxiv, 22.

Nehemiah iii, 25.

Joel iii, 17. 
As regards the method of examining their statements, I am strongly of opinion that it is not desirable to reject any statement made by them; for, even assuming that they may not always be absolutely correct, they certainly knew a great deal more about the matter than we do, and if we attempt to correct any of their information we should probably be involved in greater error; or, in other words, if a theory is not in accord with what they have written, it is more likely that the theory is incorrect than their statements that appear to contradict it. Take, for example, the assertion made by Josephus, that the hill upon which the Acra stood was cut down so as to make it lower than the Tenple, an assertion which is regarded by sone as incorrect. It appears to me, on the other hand, quite impossible to reject the fact, and no site for the Acra can be accepted which is incompatible with it.

Before describing the site which I would propose, I would like to enumerate some conclusions regarding the topography of Jerusalem upon which the proposition is based. These conclusions appear to me to be compatible with every statement in the authorities, and it is not necessary to have to explain away any record in order to meet them.

These conclusions are:-

1. From a very early date Jerusalem was a twin town, of which one part was on the western hill, and the second on the eastern hill, the two being separated from one another by the Tyropoon valley.

2. The town on the western hill was Jebus of the Jebusites, the "rest of the city" at tho time of David's attack, and the upper city of Josephus.

3. On the eastern hill was the stronghold of Zion of the Jebusites, and the City of David, afterwards called the lower city.

4. The stronghold of Zion, the Millo of David and the Kings, and the Acra of the period of the Maccabees, were fortresses which succeeded one another on one and the same site. ${ }^{1}$

5. The site of these fortresses was between the 'Temple and the City of David, and higher than both until the hill was cut down by the Asmoneans.

"In the Septuagint rersion the word "Millo," in 2 Samuel $v, 9$, is translated "Acra." The word "Tow cr," in the book of the Maccabees, is also rendered "Acris." The Septuagint version was probably made before the Acra Fas cut down in beight. 
PLAN NO1.

showing probable rock contours at present.

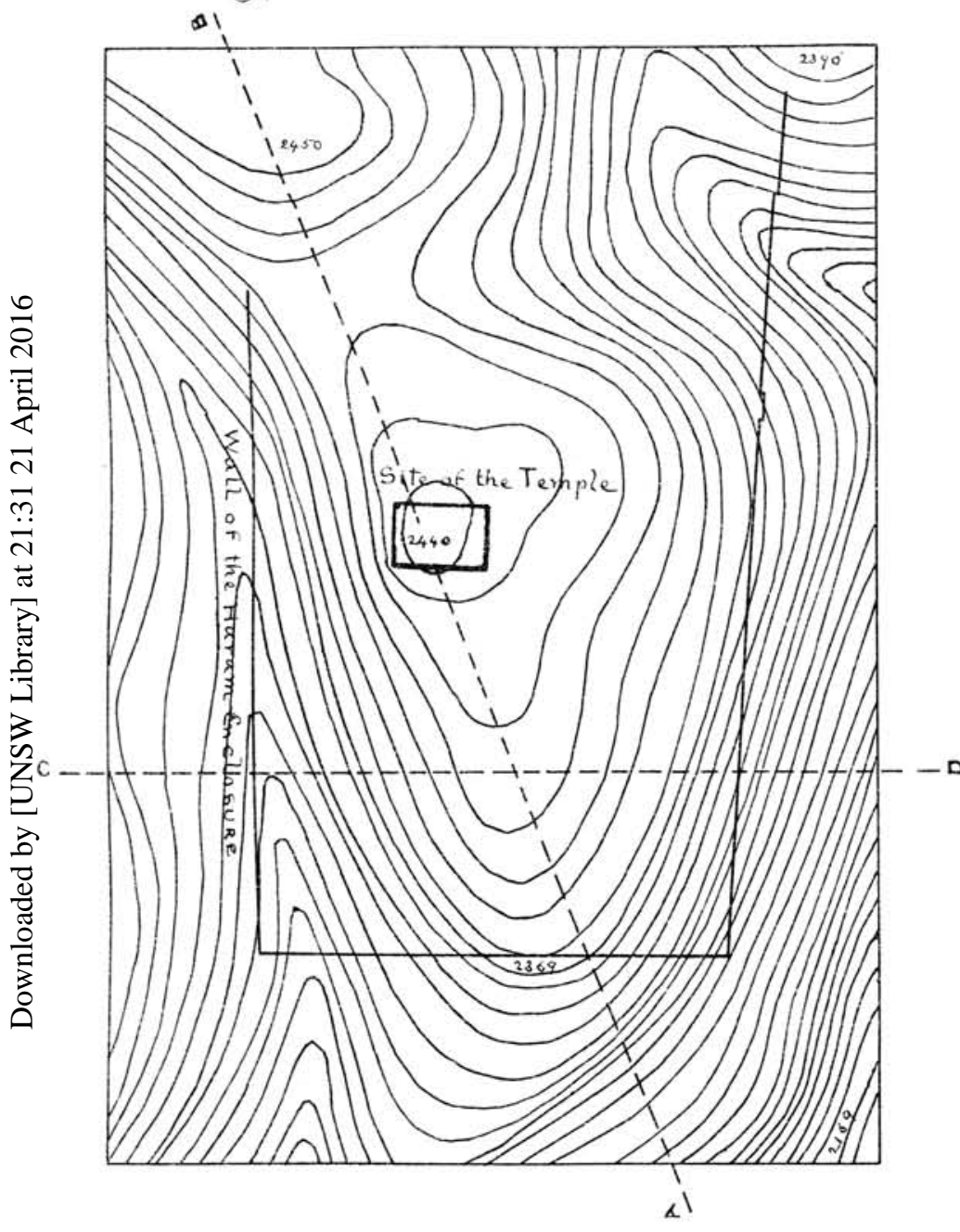

Scale

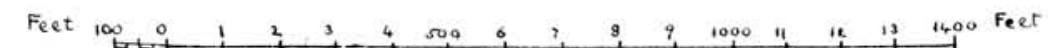

PLAN NO 2.

Showing possible rock contours before
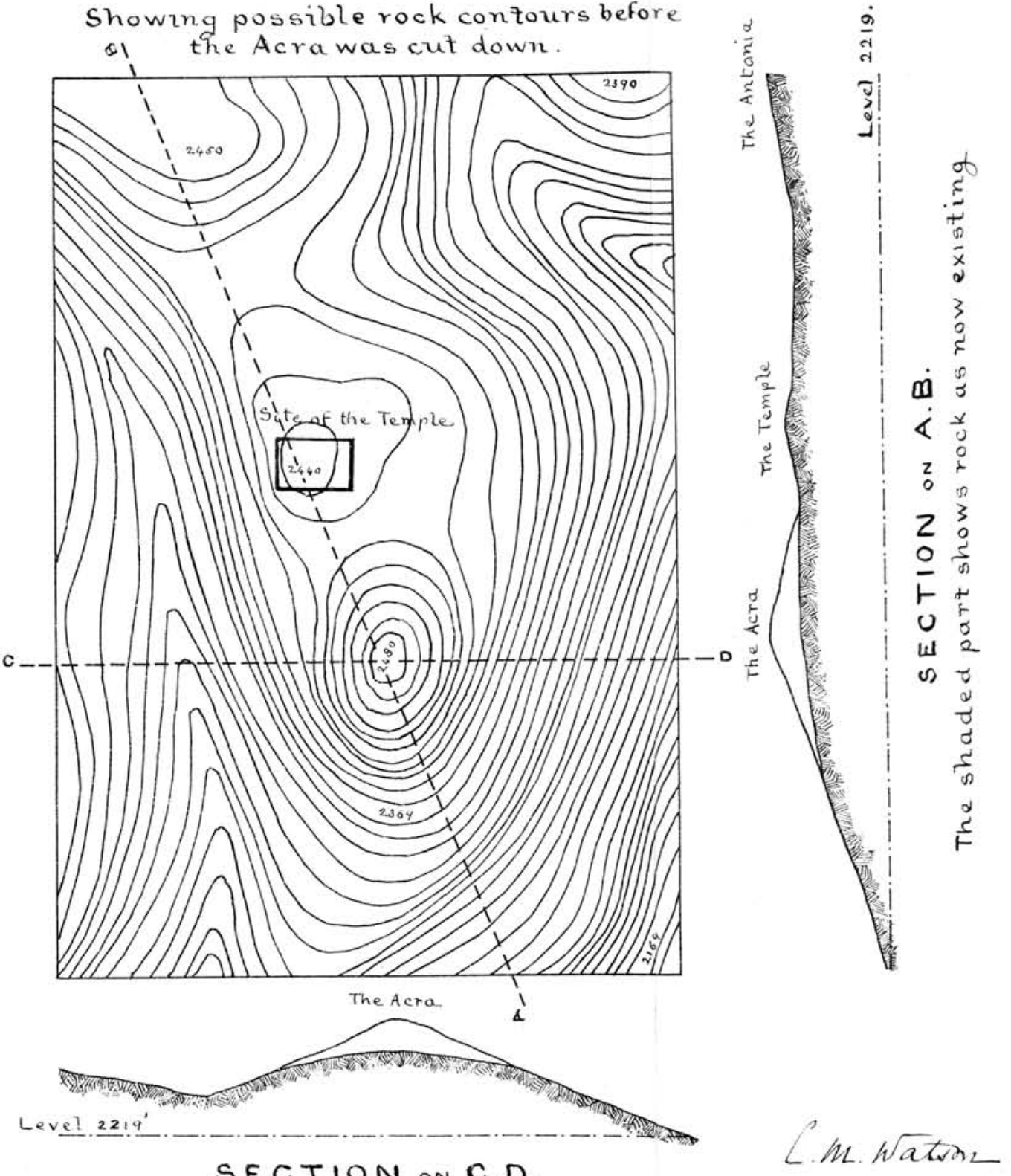

The shaded part shows rock as now existing 
6. It was north of the City of David, and south of the Temple, and so close to the latter as completely to command it.

7. After the Acra was cut down the ground sloped down from the Temple to the City of David. There was then no obstruction between the Temple and the city. ${ }^{1}$

To meet all the necessary conditions, there appears to me to be only one possible site, and this I have shown on the annexed plan. This site is within the Haram enclosure, near the north-east corner of the Mosque of Aksa, and above the great tank known as Cistern No. 8. In Plan No. 1 I have given the probable present rock contours of the hill as adopted by Sir Charles Warren, and given in the plates published with the Jerusalem Volume of the "Memoirs." These contours may not be quite correct, as they are based on limited information, but they are probably not very far from the truth, and they are as accurate as anything that can be obtained at present. These contours, of course, represent the rock after the hill of the Acra was cut down.

In Plan No. 2 I have shown the possible contours of the hill before it was levelled. I have given it a command of forty feet above the highest part of the Temple hill, which appears sufficient to meet the conditions. The two sections show the part of the hill which was cut away, assuming it to have occupied the proposed position. It appears to me that this position for the Acra would explain the reason of the existence of Cistern No. 8, which has a capacity of at least two million gallons. When the fortress was besieged by the Naccabees the garrison could not have obtained any water from outside, and yet there is no mention of thcir having suffered from want of water, although they had to surrender at

1 "So they all set themselves to the work, and levelled the mountain, and "in tliat work spent botl night and day without intermission, which cost them "three whole years before it was removed, and brought to an entire level with "the plain of the rest of the sity. After which the Temple was the highest of "all the buildings, now the citadel, as well us the mountain wherein it stuud, "were demolished."-Josephus, "Ant.," XIII, chap. rii, 7.

"But the otlier hill, which was called "Acra," and sustains the Lower City, " is of the shape of a moon when she is horned; over against this was a third "liill, but naturally lower than Acra, and parted formerly from the former iy a "hroad valley. Howerer, in those dars, when tho Asmonians reigned, thiey "filled up that valley witl "Temple. They then took off part of the height of Aera, und reduced it to "be of less elevation than it wus before, that the Temple might be superior " to it."-Josephus, "Wars," V, chap. ir, 1. 
last for lack of provisions. Possibly Cistern No. 7, another large reservoir, was also used by the garrison.

After the hill had been cut down and the surrounding walle of the Temple enclosure were built by Herod, the surface appears to have been levelled and no trace of the Acra remained. The object of its existence ceased when the new fortress, afterwards called Antonia, was built north of the Temple. Nothing then remained but the name, which, as Josephus informs us, was still applied to the slope of the hill outside the Temple enclosure.

I would observe that in the plans, Contour 2369 and those below it are the same in both plans, the alteration commencing above Contour 2369.

It would be satisfactory if some of the Members of the Fund who take an interest in the matter would state their objections to the proposed site.

\section{THE EROTIC GRAFFITO \\ IN THE TOMB OF APOLLOPHANES OF MARISSA.}

\section{By R. A. Stewart Macalister, M.A., F.S.A.}

OF the manifold details of interest which the tomb of Apollophanes of Marissa, at Beit Jibrin, presents, one of the most remarkable is the graffito scratched on the right hand jamb of the entrance to the painted chamber.

It has been discussed by Père Lagrange, in the Comptes rendus de l'Academie des Inscriptions (1902, p. 501); by Dr. Thiersch, in The Marissa Tombs (p. 57); and by Dr. Peters, at p. 75 of the same work. Each of these scholars takes a different view regarding the character and purport of the inscription. Père Lagrange considers it as a deceased wife's address to her living husband: Dr. Peters' theory is somewhat similar, but he supposes the persons involved to be lovers rather than husband and wife, and regards the inscription as being cast in dialogue form. Dr. Thiersch considers the graffito to be erotic rather than funerary, and translates it as the address of a hetaira to her lover.

Of the transcription there can be no doubt, though the character is not easy to read. Père Lagrange's copy, as is natural in a first 